Dalibor JOVANOVSKI

UDK: 323.1 (=163.3) (091)

Original research paper

\title{
THE SLOW DISCOVERY OF THE MACEDONIANS
}

\begin{abstract}
The constant claim, even in the $21^{\text {st }}$ century, that Macedonians are a nation invented by the Comintern and Tito's Yugoslavia requires research to show that the formation of the Macedonian nation was not at all a solution of an international leftist organisation, but a natural process, similar as with other nations in the region. The proximity of the Macedonian with the Bulgarian language, and partly with the Serbian language, is not at all an argument for denying the existence of the Macedonian language as a separate South Slavic language. At the end of the $19^{\text {th }}$ and the beginning of the $20^{\text {th }}$ century, the struggle led by the Macedonian Revolutionary Organisation for the creation of an autonomous Macedonian state aroused great interest among diplomats, politicians, journalists and intellectuals in Europe and the United States. As a result of that interest, many studies and pamphlets related to Macedonia and the possible solution of the Macedonian issue emerged. While seemingly the theses of the sciences from some neighbouring countries are in their favour, careful researches show something quite opposite. Namely, many perceived that the Macedonian Slavic population was neither Bulgarian nor Serbian, but separate South Slavic people appropriated by the neighbours. Moreover, in the United States, for example, where there was a right to free expression of national feeling, some Macedonian emigrants declared themselves as they felt, that is, as Macedonians.
\end{abstract}

Keywords: PEOPLE, LANGUAGE, MACEDONIAN SLAVS, MACEDONIANS

The British John Foster Fraser, travelling through the Balkans in the early $20^{\text {th }}$ century, also visited Ottoman Macedonia. In his book dealing with the Balkans, he also referred to the ethnological situation in the mentioned Ottoman area. Fraser asked himself the question: Who are the Macedonians? According to him, Bulgarians and Turks who considered themselves Macedonians could be found, Serbs and Greeks who declared themselves Macedonians could be seen, and it was possible to find Romanians who considered themselves Macedonians. He did not find a single Christian in Macedonia who was not a Bulgarian, a Serb, a Greek or a Romanian (Fraser, 1906: 5). It is noticeable that for him there were no Macedonians who were not Bulgarians, Greeks, Serbs, Romanians, even Turks. It is easy to conclude that there was no separate Macedonian nation for him, but the name Macedonian was associated with the region of Macedonia. There are other examples that speak in the direction of what Fraser wrote. Here, due to limited space, we would mention the article published in the British magazine Quarterly Review where we can read similar 
thinking as that of Fraser. According to the unsigned author of the article, the Macedonian nation did not exist as a separate one, but he used the term Macedonian to denote all the inhabitants of the region of Macedonia (Quarterly Review, 1903: 472). The author of the article found Gladstone's idea of Macedonia for the Macedonians to be completely wrong, because the latter were not separate people (Quarterly Review, 1903: 480). There are numerous other examples that do not see or recognise the existence of separate Macedonian or Macedonian Slavic people. Seemingly the things were clear to the writers, linguists, historians, journalists or diplomats of that time. However, careful research leads us to another view from which we can draw a completely different conclusion.

Czech Slavist Niederle advocated the thesis that Macedonians speak a Bulgarian dialect and have a Bulgarian national self-knowledge. However, careful reading of some of his works reveals something completely different from what this famous Czech Slavist wrote in his works. In his book, The Macedonian Issue, Niederle explains in detail the problem that burdened both European diplomacy and the relations between the Balkan states that fought against each other regarding Macedonia under the pretext of liberating their compatriots in this area. Although Niederle was a proponent of the thesis that Macedonians were Bulgarians, and their language was Bulgarian, in this book we came across an interesting thought. Writing about the nationality and language of the Macedonians, Niederle, despite his view that they were Bulgarians, wrote "With this I do not think that the question of the nationality of the Macedonian Slavs has been answered, especially if we look at some parts of Macedonia ..." (Niederle, 2014: 41). This thought of his prompted me to investigate why he wrote that the question of Macedonian nationality was unanswered, although he considered Macedonians to be Bulgarians.

Research always raises many questions, but also results in interesting findings. The question of the language of the Macedonians in the $19^{\text {th }}$ and early $20^{\text {th }}$ century was considered to have been answered and clear. Most of those who wrote about Macedonia and the Macedonians thought that the Slavic population in Macedonia was Bulgarian, but there were also those who thought

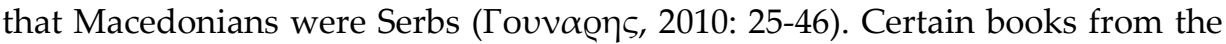
$19^{\text {th }}$ century give us interesting data that can help answer why Macedonians were not perceived as separate people or why there was a difference between defining them as Bulgarians or Serbs and later as separate Slavic people.

In the Balkans, during the first half of the $19^{\text {th }}$ century, Protestant missionaries became active who, through translations of the Bible into local dialects and languages, sought to exert their influence. The centuries-old Ottoman rule in the region resulted in oblivion of the past of the peoples of the region, but also lack of Christian theological texts in the local languages and dialects. The Bible was translated from English into one of the Balkan languages or dialects. Protestant missionaries regularly wrote about their activities in the magazine Missionary Herald. In one of the issues of this Protestant magazine we found a text concerning the translation of the New Testament into the Balkan 
languages. Thus, the Bible translation report states that the Slavic version from the time of Cyril and Methodius was incomprehensible to the common man. Thus, the priest Neophyte translated the Bible from Slavic into Macedonian dialect, and Petko Slavejkov from Greek into Eastern Bulgarian dialect (Missionary, 1867: 381). Although the author or authors of this text considered that the Macedonian and Eastern Bulgarian dialects were one language, the translation into two separate dialects shows the difference between them. Otherwise, why would the Bible be translated into Macedonian if Eastern Bulgarian was understood in Macedonia?

Mentioning the translation from Slavic into Macedonian dialect in some way raises the question of where that Slavic or more precisely Old Slavic language originated from. The answers were clear, but also interesting. The Czech Slavist and priest Josef Dobrovský, writing about the origin of the Old Slavic language, noticed that the Old Slavic language from the time of Cyril and Methodius was a Serbian-Bulgarian-Macedonian dialect, the language of the Slavs of Thessaloniki (Biblical, 1834: 346). This interesting statement by Dobrovský leads us to another thesis about the language of the Slavic population in medieval Macedonia, which in the $19^{\text {th }}$ century and later was denoted as an old Bulgarian or Bulgarian variant of the Old Slavic language. This is certainly related to our topic, but also to the attitude towards the determination of the belonging of the Macedonian population. In 1916, an article by Prince appeared about an Old Slavic text, a Croatian version, written in Glagolitic in a private library in New York. According to Prince, it was completely wrong to name the Old Slavic language, originating in Macedonia, as Old Bulgarian (Prince, 1916: 359). For him, the non-Slavic Bulgarians accepted the Slavic idiom which was less different from the Serbian and Russian ones in relation to the Church Slavic form of the Macedonian one. We can conclude that he distinguished between the medieval Old Slavic language spoken in Macedonia and that of the slovenised Bulgarians. In this regard we would mention a book that appeared in England in the $18^{\text {th }}$ century and referred to the Slavic languages. According to the author of the book, Western Macedonian belongs to the Slavic languages (Brerewood, 1774: 70). All this leads to a logical question whether there were, that is, whether foreign scientists, travel writers, journalists or diplomats perceived Macedonians as holders of a separate national element, irrespective of whether they called them Macedonians, Slavo-Macedonians or Macedonian Slavs? The answer is yes. It should be said openly that they were in a smaller number than those associating the Macedonians with the neighbouring nations, especially the Bulgarians.

The outbreak of the Great Eastern Crisis in 1875 brought the Balkans back into the spotlight of European governments and the public. In the European countries, the events in the region were followed with great interest, the European powers showed great activity in order to calm down the situation, but also to accomplish their interests. The latter was especially important for Russia and Austria-Hungary. The European press repeatedly reported on the Bal- 
kan situation, and many books, articles and propaganda brochures on the region and its future were also published. Some intellectuals and diplomats from the Balkan countries were also active, hereby meaning of those from independent Greece and autonomous Serbia. Thus, the influential British Macmillan's Magazine published an article on the Eastern issue from the Balkan point of view. The author of the article was signed with a pseudonym and according to the signature he was a Serb. The article itself would not be interesting for our work if Macedonia was not mentioned in it. For the author, Serbs and Bulgarians lived in Macedonia, but also other people that he named Macedonians (A Servian, 18761877). According to him, the number of the Macedonians was $1,000,000$. Very interesting is his position on the language of the Macedonians, as he calls them, which was between the Serbian and Bulgarian dialects (A Servian, 1876-1877: 161). This thinking will be shared by other authors in the future.

The emergence of the Macedonian Revolutionary Organisation in 1893, and its struggle for Macedonia's autonomy, contributed to the actualisation of the Macedonian issue in the early $20^{\text {th }}$ century. Many journalists, politicians, diplomats and scientists showed an interest in Macedonia and the situation with its population. Of course, the ethnological situation, as they experienced it, was also part of that interest. It would not be scientifically correct if I do not mention that many of them even then brought the Macedonians into connection with the Bulgarians. However, it was more and more noticeable that the Macedonian struggle was autochthonous and that the Macedonian population was not Bulgarian. The events in Macedonia were also of interest to scientists from Slavic countries or countries with large Slavic populations, such as AustriaHungary. A book was issued in Vienna in 1903 explaining the situation in Macedonia. The author of the book dealing with Macedonia and the problems in Turkey was a certain Gersin. In fact, the Slovenian Niko Županić was behind this pseudonym. Unfortunately, we did not use the book, but criticism on it was published in Ljubljansko Zvono. The criticism speaks of Slavic Macedonians and their struggle for freedom against the Ottoman government. We learn from it that the author estimated that the majority of the population in Macedonia consisted of the Macedonian Slavs who numbered 2,146,336 (A.A., 1903: 314-315). The following year already, Nico Županić published a study on Macedonia, its history, culture and ethnic composition. Here we will focus on his thinking about Macedonians and the question of whether they were separate people in relation to Bulgarians and Serbs, an issue that increasingly preoccupied scientists, politicians and diplomats. Writing about Macedonian history, Županić noted that one of the saddest moments for the Macedonian Slavs was the abolition of the Ohrid Archbishopric in 1767 and its annexation to the Constantinople Patriarchate (Županić, 1904: 79). We deliberately emphasise this as, unlike many other authors, he does not associate the Ohrid Archbishopric with Bulgaria. Also, for him, the Kingdom of Samuel is a Shopi-Macedonian state (Županić, 1904: 88). Županić is very careful when talking about the issue of the existence of Macedonians, but we can still conclude that, using the name Shopi 
Macedonians, and mentioning such a language, he separates them from Bulgarians and Serbs, although he believes that the lack of developed national consciousness can led to their assimilation (Županić, 1904: 86-88). A similar interest in the Macedonian situation was shown in the Czech Republic. The famous lawyer Bohumil Baxa published the article Macedonian Question in an influential magazine there. Therein, he referred to the ethnic composition of the population in Macedonia. According to him, the majority of the population consisted of Macedonian Slavs, who were appropriated by both Bulgarians and Serbs (Baxa, 1903:714). Baxa is very careful in naming the Macedonians; while we can see that he restrains himself from claiming that they are separate people, he names them Macedonian Slavs. Karasek, who published a smaller study of the language of what he calls the Macedonian Slavs, thought similarly to Baxa. Karasek considered that the nationality of the Macedonian Slavs could be determined after a thorough study of their language, and considered Serbian and Bulgarian claims to be political and part of their propaganda (Karasek, 1903: 116-117). It is interesting to note that he believed that most of the population felt Macedonian, but intellectuals divided themselves into Serbs and Bulgarians (Karasek, 1903: 117). This remark is probably correct and will later have an impact on resolving the Macedonian issue.

Macedonians are South Slavic people who have their own language, unfortunately still disputed today, although Slavic studies, with the exception of Bulgarian, long ago recognised it as a separate language. Therefore, in this part of the work an example will be given that shows how some Slavic scientists looked at the Macedonian uniqueness. Professor P.E. Kazanski from Odessa in his report on the All-Slavic Assembly in the Bulgarian capital gave some thoughts on future action. Among other things, he noted that not all political parties were represented at the Assembly, such as also the less developed "Slavic tribes (Macedonians, Luzicans)" (Славянскиій, 1910: 30). This only shows us that in some Russian circles the existence of separate Slavic people - the Macedonians - was already clear.

The end of the Balkan Wars, the expulsion of the Ottomans from the region and the division of Macedonia among the Balkan states did not mean the end of the issue of the belonging of the Macedonian population. Joerg in his study dealing with the new borders in the region and the issue of the fate of the population also referred to Macedonia. According to his thinking, Macedonians should be considered as Slavs who are between Serbs and Bulgarians (Joerg, 1913: 829). Such thinking was not new and it continued to be elaborated in the next period.

The establishment of the Macedonian Front in the First World War, where the armies of the Entente and the Central Powers fought fierce battles, caused great suffering to the local population. However, officers of the warring parties, journalists, and ordinary soldiers began writing books and articles about the military operations themselves, which also addressed the local population. Italian Luigi Villari was a liaison officer in the British command of the 
Macedonian Front. A decade after the end of World War I, one of his articles on the Macedonian issue was published. It is interesting to note that Villari believed that Macedonians were more inclined towards Bulgaria than towards Serbia, but still ranked them as separate people. According to him, the three peoples - Serbs, Bulgarians and Macedonians - spoke very similar Slavic languages. History has divided Serbs and Bulgarians, and Macedonians have been ethnically and linguistically between them (Villari, 1928: 152). The British Douglas Walsh was on the Macedonian front and after the end of the military operations he published a book in which he expressed his impressions. In his book dealing with the events on the Macedonian front he also referred to the local population and, of course, to the actions of the British soldiers. What is interesting about the topic we are dealing with is his remark about the language, more precisely, one of the languages spoken in Macedonia. Writing about Slavic Muslims, he noted that they spoke Macedonian, or, as he wrote, macedonski (Walshe, 1920: 188). Describing the daily life of a British soldier at the front, Walsh also talked about the tongues that the soldier listened to and here he mentioned the language as macedonski (Walshe, 1920: 199).

Villari and Walsh's views on the Macedonian population and the language they spoke were not the only ones in this period, that is, in the period of the First World War. Although military operations were the main public interest at the time, scientists were busy with their topics and researches. The issue of the Macedonians and their language, that is, whether it existed as an independent or was a dialect of another Slavic language, primarily Bulgarian, continued to be a topic in some articles. In his paper on linguistic areas in Europe, Leon Dominian also referred to the situation in Macedonia, which had already been part of four Balkan countries. Although he considered Macedonians and their language to be more Bulgarian, a careful reading of his article showed some uncertainty on the issue. Dominian writes that Macedonians as people are a transitional element between Serbs and Bulgarians. He states the same about the Macedonian language (Dominian, 1915: 436). A year later, Buck's study of language and nationality appeared. Unlike Dominian, Buck compares the language problem of Macedonians to some other examples from the Slavic world. According to him, there are questions whether the Slovak language is a separate language or a dialect of Czech, whether Ukrainian is a separate language or a dialect of Russian and, what is interesting for us, whether the Slavic language in Macedonia is Bulgarian, Serbian or Macedonian Slavic (Buck, 1916: 61). For him, linguists are divided over this issue. These two examples show us how difficult it was to recognise the fact that the Macedonian language, although not yet codified, still existed in the same way as the spoken languages that were not and are not codified.

It is interesting to note that during the First World War there was a long and bitter discussion between Hermann Wendel, a German MP from the Social Democratic Party, and Dimitar Rizov, a Bulgarian diplomat of Macedonian descent. For Rizov, who originated from Bitola, the nationality of the Macedo- 
nians was clear - they were Bulgarians. We find the opinion of Wendel to be more interesting. Wendel was accused by Rizov of having pro-Serbian views when it came to Macedonia and the local Slavic population. However, careful reading of Wendel's texts does not lead to the conclusion that he did not consider Macedonians to be Bulgarians or Serbs, but separate Slavic people who, still, due to historical circumstances, had not built a solid national awareness (Вендел, Ризов, Томиќ, 2014: 5-8, 17-23). It is interesting to note that Wendel, in the discussion with Rizov, also referred to authors who considered that the Macedonians were neither Bulgarians nor Serbs. We are interested in the opinion of Theobald Fischer, who, as Wendel shows us, considered that "the majority of the Macedonian population is neither Serbian nor Bulgarian, but is formed by the southern Slavs in Macedonia without a clear national feeling" (Вендел, Ризов, Томиќ, 2014: 7). It should be noted that Wendel and Rizov during the First World War were representatives of two allied countries within the Central Powers - Germany and Bulgaria. After the war, Wendel himself visited the part of Macedonia that was part of the newly formed Kingdom of Serbs, Croats and Slovenes and elaborated his impressions in one of his books. During the visit to Macedonia, in Resen Wendel asked a group of children what their nationality was and they answered - Macedonians, and in neighbouring Bitola he met a local intellectual who spoke to him about the separate Macedonian nationality and the desire to create a Macedonian autonomous area with a seat in Skopje (Wendel, 1922: 92).

During World War I, there were scientists from various fields in the armies of the Central Powers who fought on the Macedonian front, and previously on other Balkan battlefields, who did certain studies and then published them or gave lectures on topics related to the Balkans. One such lecture was given in Vienna in March 1917 by Professor Eugene Oberhummer entitled "The Balkan Peoples". The part about the population of the peninsula is interesting for us. This Austro-Hungarian geographer noted that the controversy over the belonging of Slavic Macedonians was particularly violent, although they increasingly called themselves Macedonians (Oberhummer, 1917: 296298). Oberhummer believed that further clarification was needed on the language of this population.

After the end of World War I, one of the most pressing issues in Europe concerned national minorities in the newly created states as a result of the war and the Paris Peace Conference. Interesting books and articles appeared that referred to the Macedonians, among other things, specifically whether they were separate people. Here some examples will be given of the separate Macedonian national identity. The creation of a new Yugoslav state called the Kingdom of Serbs, Croats and Slovenes also aroused scientific interest in its ethnic composition. In the new Yugoslav state Macedonians were not recognised as separate people, but were considered Southern Serbs. However, in a Slovenian magazine we can see an interesting reasoning. Anton Loboda, writing about the problem of the Macedonian population and appropriation by Serbs and 
Bulgarians, noted that a stream appeared among the Macedonians that considered the Macedonian Slavs to be separate South Slavic people (Loboda, 1918: 65). Loboda's writing was not the only one and alone. In his book on the history of Serbia, the British historian Temperley also addressed the issue of the existence of Macedonians. Like the others during this period, he wrote about the different views on the belonging of the Macedonian population, but also the poorly developed national awareness among the Macedonian population. Although seemingly writing about Bulgarians, Temperley noted that there was a Macedonian people and a Macedonian language, which was separate in view of Bulgarian and Serbian, although it was quite similar and adaptable (Temperley, 1919: 312). Bowman writes much like Loboda and Temperley. In his book on political geography and the new world after the First World War, he also paid attention to the situation in the Balkans, and Macedonia and the Macedonians could not be left out. Bowman published a map that clearly marked the Macedonians as separate people in the region that inhabited parts of the Kingdom of SCS and Greece (Bowman, 1922: 234). For him, Macedonians were a separate nation different from Bulgarians.

The existence of Macedonians as a separate nation with their own language was not emphasised by foreign intellectuals, scientists and journalists only, but in some Western publications it was promoted by the Macedonians themselves. In the research, we came across an article published in a French magazine by a certain Goce, a name that is probably a pseudonym of the author. In the article entitled "Macedonian idea. The Union of Balkan Peoples ", the author explained the situation in Macedonia and the Macedonian struggle for freedom against the Ottoman rule. Although he advocated the freedom of all peoples in Macedonia and the creation of a Balkan federation, the author noted that Macedonians spoke a Slavic language and lived together with Greeks, Romanians, Albanians and Jews (Gotse, 1928: 9). He does not mention anywhere that the Macedonian language is Bulgarian or Serbian, nor does he write that Macedonians are Bulgarians or Serbs.

The difficult social, economic and, above all, political situation in Ottoman Macedonia caused the emigration of the local population, primarily the Christian population, to other parts of the world. Macedonians were no exception to this process. For the first time they could see a new prosperity in a world where life was not as dangerous as it was in the Ottoman Empire. Macedonian emigrants had the opportunity, due to American democracy, to freely express their identity and to declare themselves as Macedonians who speak the Macedonian language, which was not codified at the time and was not recognised in the Ottoman Empire and by its neighbours and linguistics. However, that process was not simple and easy. The example of the demarcation of the Macedonian language in the early $20^{\text {th }}$ century in the United States is a good indicator. The influence of the linguistic debate on the affiliation of the Macedonian language can be seen in the American official documents as well. It should be noted that initially in the American official books we notice a confusion over 
the question of who the Macedonians are, that is, whether they are separate people with their own language or are part of the Bulgarian people. In 1911, an edition was published in several volumes for the needs of the American immigration system and government. And here we encounter the same confusion about the Macedonians. Namely, in one of the volumes that refers to the origin and language of the immigrants, there is a very interesting part that refers to the Macedonians. Specifically, in the section entitled Macedonians it is briefly stated see Bulgarians (Dillingham 1, 1911: 92). At first glance, things are clear and precise, but this is not the case. Namely, in the part that refers to the Bulgarians, when it comes to the language, we notice the whole ambiguity about the Macedonians. The instructions to those who registered the immigrants, their origins and their mother tongue noted that it was necessary to explain the issue they considered most important concerning the Bulgarian dialects, that is, the so-called Macedonian language. According to what was written, there were people who claimed that there was a Macedonian people and language, but that was considered a kind of local patriotism, because at that time the linguists from the Balkan region were not familiar with such a thing (Dillingham 1, 1911: 27). As I wrote, at first glance everything was clear, but the explanation itself gives room for different interpretations. In the same edition we find something that is the best denial of what is written and is a confirmation of the already clearer Macedonian national awareness different from the regional one which was connected with the Bulgarians and the Greeks, even the Serbs. Namely, although the same thesis about the Macedonian language was repeated, the compilers of these reports wrote: "Occasionally an immigrant from Turkey insists that he is Macedonian, not Turkish, Bulgarian, Greek or Albanian" (Dillingham 2, 1911: 282). In that direction, in several places in this volume of the same edition, the noun Macedonian and the adjective Macedonian stands without any additions as an expression of a separate identity (Dillingham 2, 1911: 356-530). Two decades later, the question of the language and nationality of Macedonians, in these American statistical books published on the question of immigrants, is much clearer. Thus, in the instructions to those who were supposed to fill in the census graphs, Macedonian was recorded as one of the mother tongues (Instructions, 1930:30). This change was the result, we assume, of the hesitations that existed in the beginning with the American services, but also of the insistence of the Macedonian immigrants that their language be registered as Macedonian. An example of this thinking is an article in an American daily newspaper. An article appeared in the Harrisburg Telegraph in which, in addition to Slavic and English, Macedonian was mentioned as a language in which a circular letter would be printed for the needs of the city (Harrisburg Telegraph, 1914:3). When it comes to North America, we would like to note that at the beginning of the $20^{\text {th }}$ century Macedonian emigration also existed in Canada, then a British dominion. So far, we do not have official Canadian data, as in the case with the U.S., but there is an interesting book concerning Canadian emigrants. The book contains quite interesting data about the Macedoni- 
ans, that is, their uniqueness in relation to other peoples of the Balkans. Here, for the sake of space, we will mention a classification of the Slavic peoples. The author of the book, according to scientific knowledge, divides the Slavic peoples into Eastern, Western and Southern Slavs. The division of the last South Slavic group of peoples is interesting for us. Thus, we can see the following classification - Southern Slavs are divided into Bulgarians, Macedonians, Serbs, Montenegrins, Bosnians and Herzegovinians and Croats (Cameron, 1913:34). In other parts of the book, Cameron clearly distinguishes Macedonians from other peoples. We can simply note that Macedonians in the new world could express themselves and fight for what they are, without being exposed to the pressure of the propaganda of neighbouring countries claiming Macedonia, and later of their governments after the division of the region in 1913.

In the end, the question arises why so late, with so much doubt and so difficult a people in the Balkans is perceived and recognised, and that people is the Macedonian one? The answer seems easy, but it is essentially delicate and extensive. The initial poor knowledge of the situation in the Balkans and in Macedonia and the easy adoption, first of the Bulgarian name, and later of the Serbian one by foreign scientists, diplomats, travel writers and journalists had their impact on the view of the ethnological situation in Macedonia and the question of existence of the Macedonians as separate people. We found one of the most interesting explanations for the problem of the Macedonians in a book published during the Second World War, that is, before the creation of the Macedonian state. According to Kovacs, the author of the book, the majority of the population speaks Macedonian, which Serbs call Southern Serbian, Bulgarians consider Bulgarian, while Greeks call them Slavic-speaking population. The most important thing for him is the fact that no one asked the Macedonians themselves about their opinion (Kovacs, 1943: 56).

\section{References:}

A.A, 1903, "K. Gersin, Macedonien und das Türkische problem", Ljubljanski zvon, 314-315.

A SERVIAN, 1876-1877, "The Eastern Question from the point of view of the Eastern Christian", Macmillan's Magazine, 35, 158-176.

BAXA Bohumil, 1903, “Macedonska otazka", Česka revue, 6, 708-715.

Bowman Isaiah, 1922, The New World. Problems in political Geography, New York: World Book Company.

BREREWOOD Edward, 1774, Enquiries touching the diversity of languages and religions through the chief parts of the world, London: S.M.J.M and H.H.

BuCK, Darling Carol, 1916, "Language and the sentiment of Nationality", The American political Science Review, v. 10/1, 44-69. 
CAMERON, R.J., 1913, Foreigners or Canadians?, Toronto: The Standard Publishing Co.

DiLlingHAM William, 1, 1911, Reports of the immigrants Commission, Dictionary of Races or Peoples, Washington: Government printing Office.

DiLlingHAM William, 2, 1911, Reports of the immigrants Commission, Abstracts of Reports of the Immigration Commission, Washington: Government printing Office

DOMINIAN, Leon, 1915, “Linguistic areas in Europe: Their boundaries and Political significance", Bulletin of the American Geographical Society, v.47/6, 401439.

FRAZER FOSTER, John, 1906, Pictures from the Balkans, London: Cassell and Company, ltd.

GOTSE, 1928, “L'idee macedonienne. L'Union des peoples balkaniques”, Le cri des peuples, $1 / 6$, Paris, 9.

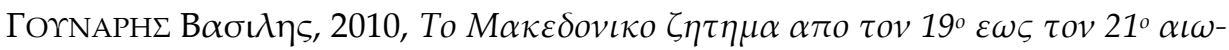

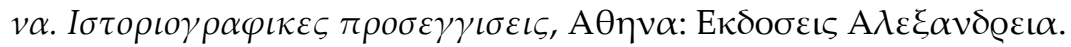

"Historical view of the Slavic language in its various dialects with the special reference to the theological literature", 1834, Biblical repository, vol. XIV, New York, 328-412.

Instructions tO ENUmERATORs. Populations and Agriculture Fifteenth Census, 1930, Washington: Government printing Office.

JoERG, W.L.G., 1913, “The New Boundaries of the Balkan states and their significance", Bulletin of the American Geographical Society, v. 45/11, 819-830.

KARASEK Josef, 1903, "Několik slov o makedonskýh Slovanech", Slovanský Přehled, $r$. V, 113-119.

KovACS Frederick, 1943, The Untamed Balkans, New York: Modern Ages Books.

LOBODA Anton, 1918, "Misli o slovanskih narodnostnih problemih", Ljubljanski zvon, XXXVIII, 64-73.

НИДЕРАЕ, Аибор, 2014, Македонското прашане, Скопје: АД Вербум.

OBERHUMMER, Eugen, 1917, Die Balkanvölke, Wien: Vortag.

PRINCE Dyneley J., 1916, "A Rare Old Slavonic Religious Manual”, Proceedings of the American Philosophical Society, v. 55/6, 357-362.

СЛАВяНСКИІй СъЕЗДъ Въ СОФІИ, 1910, Отчетъ представитела Императорскаго Новороссійскаго университета ординарнога профессора П.Е. Казанскаго, Одеса.

TEMPERLEY Harold, 1919, History of Serbia, London: G. Bell and Sons.

“The Macedonian maze", 1903, Quarterly review, N. 394, April, 459-483.

"Translators of the Bible in Constantinople", 1867, Missionary Herald,, v. LXIII, n. XII, 379-392.

ВЕНдЕд Херман, Ризов Димитар, Светозар Томиќ, 2014, За Македонија и Македоничите, Скопје: Pro Macedonia. 
VILLARI Luigi, 1928, “The Macedonian problem”, Royal UnitedService Instution Journal, 73, 151-157.

WALSHE, Douglas, 1920, With the Serbs in Macedonia, London: John Lane Bodley Head.

WENDEL, Herman, 1922, Von Marburg bis Monastrir, Frankfurt M: Frankfurter Societats-Druckerei.

ŽUPANIČ Niko, 1904, "Macedonija (etnografska skica)", Zbornik naučnih i poučnih spisov, z. VI, 71-101.

Newspapers:

Harrisburg telegraph, May 5, 1914. 